\title{
Significant decomposition of riverine humic-rich DOC by marine but not estuarine bacteria assessed in sequential chemostat experiments
}

\author{
Veljo Kisand $^{1,2, *}$, Dagmar Rocker ${ }^{1}$, Meinhard Simon ${ }^{1}$ \\ ${ }^{1}$ Institute for Chemistry and Biology of the Marine Environment, University of Oldenburg, PO Box 2503, \\ 26111 Oldenburg, Germany \\ ${ }^{2}$ Present address: Institute of Technology, University of Tartu, Nooruse 1, Tartu 50411, Estonia
}

\begin{abstract}
Humic substances (HS) are the most abundant natural organic compounds in aquatic and terrestrial environments. However, the bacterial degradation of HS in the estuarine salinity gradient and in coastal regions as a sink for HS, entering the open sea, is not well understood. Therefore, we studied the bacterial degradation of humic-rich dissolved organic carbon (DOC) at increasing salinities between 1 and 30 in an estuary of the southern North Sea (Weser). Three-stage chemostats, inoculated with natural brackish (salinity 5 and 15) and coastal marine (salinity 30) bacterial communities fed $0.1 \mu \mathrm{m}$ filtered natural humic-rich freshwater adjusted to the respective salinity, were run for up to $51 \mathrm{~d}$ at dilution rates of 0.1 and $0.15 \mathrm{~d}^{-1}$. DOC concentrations, bacterial numbers, and production were assessed in each stage over the incubation time. In addition, the fulvic acid (FA), humic acid (HA), and hydrophilic acid (HPA) fractions of the HS were determined by XAD fractionation. At a salinity of 30, the humic-rich DOC was decomposed to more than $60 \%$, whereas in the other 2 experiments at salinities of 15 and 5, no detectable decomposition occurred. At the highest salinity condition, all 3 HS fractions were reduced substantially, whereas at a salinity of 5 , only the HA and HPA fractions decreased, and at 15, only the HA fraction decreased. In the latter experiments, concentrations of the FA and HPA fractions in some chemostat stages increased despite unchanged DOC concentration. Our study provides evidence that the main bacterial decomposition, i.e. conversion into bacterial biomass and remineralization, of humic-rich DOC occurs in the polyhaline estuarine region and that at lower salinities, only some transformation of the humic fractions takes place, modifying the adsorptive properties of the HS, but no bacterial DOC decomposition occurs. The sequential chemostats were a useful approach to study the complex process of bacterial HS decomposition.
\end{abstract}

KEY WORDS: Humic substances $\cdot$ DOC $\cdot$ Bacteria $\cdot$ Chemostat $\cdot$ Estuary $\cdot$ Marine

Resale or republication not permitted without written consent of the publisher

\section{INTRODUCTION}

Humic substances (HS) are the most abundant natural organic compounds in aquatic and terrestrial environments. They represent up to $25 \%$ of total organic carbon on earth and up to $50 \%$ of organic carbon in freshwaters (Aiken et al. 1985). Despite considerable discharge of river water into the sea, the terrigenous dissolved organic matter (DOM) comprises only a small fraction $(0.7$ to $2.4 \%$ ) of the total DOM in the ocean (Opsahl \& Benner 1997).
HS are usually defined as organic compounds of different solubility at low $\mathrm{pH}$ or adsorbed to various types of hydrophobic macroporous resins at low pH (e.g. XAD-2, XAD-4, XAD-8) and eluted by alkaline solutions and hydrophobic eluants (e.g. Thurman \& Malcolm 1981, McKnight \& Aiken 1998). The major compounds isolated by these procedures include the 2 hydrophobic fractions: fulvic acids (FA), with a molecular weight range of 500 to $1200 \mathrm{Da}$, and humic acids (HA), which represent the high molecular weight fraction. The third fraction, hydrophilic acids (HPA), has 
the lowest molecular weight, i.e. $<600$ Da. Riverine inputs of dissolved organic carbon (DOC), of which HS comprise a substantial fraction, constitute the major flux of such compounds into the coastal zone.

Flocculation at increasing salinity is one important process of DOC removal during the estuarine passage (Sholkovitz 1976, Sholkovitz et al. 1978, Kerner et al. 2003), but photochemical and bacterial degradation also contribute to this removal (see below). Present estimates imply that terrestrial and thus humic DOC, after mixing with seawater, is degraded rapidly in the coastal zone (Hedges et al. 1997, Cauwet 2002, Mannino \& Harvey 2004). Hence, estuaries, the transition zone between freshwater and coastal marine environments, presumably are of prime importance for the degradation and thus for losses of riverine and terrestrial DOC.

Degradation, formation, and transformation of HS are complex processes. Heterotrophic bacteria are the major decomposers of HS in aquatic ecosystems, converting them into biomass and remineralizing them to inorganic carbon. However, heterotrophic bacteria may also produce refractory HS, especially in the marine environment (e.g. Ishiwatari 1992, Tranvik 1998, Ogawa et al. 2001). Physico-chemical processes, particularly flocculation and photochemical reactions, also play a role in the formation of recalcitrant DOC (Obernosterer et al. 1999, 2001, Obernosterer \& Herndl 2000, Kerner et al. 2003). On the other hand, photochemical transformation is an important pathway to decompose recalcitrant DOC (Moran \& Zepp 1997, Obernosterer et al. 2001).

For soil HS, a steady state of formation and degradation can be assumed. This can also be largely applied to freshwater HS, despite increased UV radiation levels at the surface waters in lacustrine environments compared to soil, presumably enhancing the degradation of HS. When reaching the estuarine transition zone between saline and freshwater, HS are exposed to new conditions. Salinity plays an important role in enhancing the decomposition rates of highly refractory HS (e.g. Wikner et al. 1999). When HS enter brackish and marine ecosystems, the increased salinity and ionic strength of the saline environment may enhance the degradation rate of HS dramatically. However, the role of HS degradation in estuarine gradients and in coastal regions as a sink for DOC/HS, entering the open sea, is not well understood (Cauwet 2002, Søndergaard et al. 2003, McKenna 2004). Most data indicate that loss rates of riverine DOC during initial mixing in the estuarine salinity gradient cannot explain the rapid disappearance of terrigenous DOC during the passage through this transition zone. Only a small fraction of riverine DOC appears to be degraded during the estuarine mixing, and this degree of degrada- tion increases with the residence time of the DOC. It is likely that a substantial part of the degradation occurs in more extended coastal regions, bringing terrigenous DOC concentrations eventually to trace levels in the open sea. However, detailed studies of the bacterial degradation of humic-rich DOC under these conditions are still scarce.

The present challenge is to understand the general observation that terrestrial HS is largely missing from the marine ecosystem, and to apply refined analytical tools for the identification of mechanisms transforming and/or mineralizing the allochthonous riverine HS. One way to shed light on the complex mechanisms such as degradation of terrestrial HS in estuaries and the coastal zone is to design laboratory experiments in which several key parameters are controlled and their influence on the degradation of HS and changes of the bacterial community composition can be reliably measured. Traditional batch cultures do not mimic the conditions met in the natural environment in an appropriate way. Therefore, we developed an approach using sequential chemostat cultures to simulate stepwise degradation of the HS under well controlled conditions. These cultures were used to study the degradation of freshwater-borne HS by estuarine bacterial communities covering the salinity range from the oligohaline (salinity 5), mesohaline (salinity 15 ) to the polyhaline region (salinity $\sim 30$ ).

The main aims of this study were to assess the degradation of HS and its constituents and the efficiency of the bacterial decomposition, i.e. relative proportions of biomass production and mineralization, of HS at increasing salinity in sequential chemostats. We postulate that the humic-rich DOC is decomposed differently at the various salinities and that different degrees of HS decomposition occur in different stages of these cultures, i.e. degradation of more refractory material in the 'later' stage with a lower growth efficiency.

\section{MATERIALS AND METHODS}

Approach. Simple, laboratory-built chemostats were used to grow estuarine bacteria on HS-rich freshwater adjusted to various estuarine salinities. The bacterial inocula originated from the oligo- to mesohaline section (salinities of 5 and 15) of the Weser estuary, northwestern Germany $\left(53^{\circ} 21^{\prime} 44^{\prime \prime} \mathrm{N}\right.$, $08^{\circ} 29^{\prime} 41^{\prime \prime} \mathrm{E}_{i} 53^{\circ} 26^{\prime} 40^{\prime \prime} \mathrm{N}, 08^{\circ} 29^{\prime} 07^{\prime \prime} \mathrm{E}$ ), and from the polyhaline (salinity 30) Wadden Sea at Neuharlingersiel, northwestern Germany $\left(53^{\circ} 43^{\prime} 20^{\prime \prime} \mathrm{N}\right.$, $07^{\circ} 43^{\prime} 20^{\prime \prime} \mathrm{E}$ ). The HS-rich water was collected from 2 humic-rich streams in the hinterland of the Wadden Sea (Esens region, northwestern Germany; total DOC up to $5.2 \mathrm{mM} \mathrm{C}$ ) on 11 May and 2 December 2003. 
Set up of the chemostats. Three experiments were carried out. Expt 1, with the bacterial inoculum of salinity 30 (Wad30) from the Wadden Sea, was run in duplicate chemostats at $20^{\circ} \mathrm{C}$. The 2 other experiments, inoculated with bacteria from regions with salinities of 5 (Wes5) and 15 (Wes15) of the Weser estuary, were run in 1 replicate at $15^{\circ} \mathrm{C}$. The bacterial inocula were pre-filtered through $0.8 \mu \mathrm{m}$ isopore filters to avoid growth of bacterial grazers in the chemostat cultures, and $1000 \mathrm{ml}$ of the inoculum $\left(1 \times 10^{6}\right.$ bacteria $\left.\mathrm{ml}^{-1}\right)$ were added to the first chemostat prior to pumping in the medium. Chemostat Stages II and III were subsequently filled by the overflow of the previous stage such that Stage II started to run 5 (Wes5, Wes15) and $8 \mathrm{~d}$ (Wad30), and Stage III 18 (Wes5, Wes15) and 24 d (Wad30), after the start of Stage I. Grazers were never observed in the cultures.

The chemostats were built from pre-combusted $(2 \mathrm{~h}$ $\left.500^{\circ} \mathrm{C}\right) 121$ glass bottles, acid-washed silicon stoppers, and silicon tubes, and were set up in a 3 stage sequence (Fig. 1). Peristaltic pumps (8 channel Ismatec MCMS/CA8) were used to pump the medium into and out of the chemostats, which contained 101 of medium. The pumps were operated at a dilution rate of $0.1 \mathrm{~d}^{-1}$ (Wad30) or $0.15 \mathrm{~d}^{-1}$ (Wes5 and Wes15). The chemostats were continuously aerated using room air (filtered through 0.22 $\mu \mathrm{m}$ filters). The outflow from the last chemostat was filtered through $0.22 \mu \mathrm{m}$ capsule filters (Mini capsule filters HT Tuffryn, Pall Life Sciences) and collected into acidwashed plastic (PE) containers (Fig. 1). They were stored at $4^{\circ} \mathrm{C}$ until XAD extraction (see 'Extraction of HS using XAD resins' below). Subsamples of $150 \mathrm{ml}$ for further analyses were withdrawn from each chemostat stage at

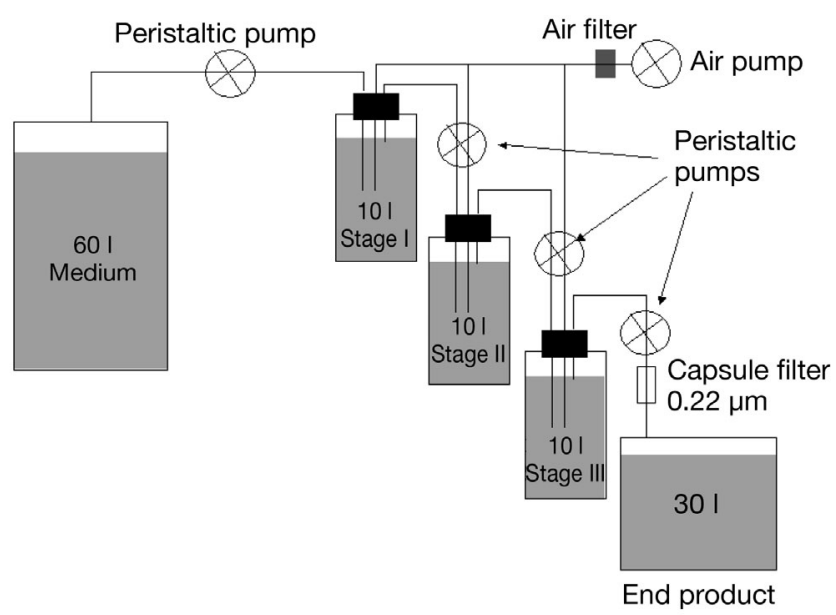

Fig. 1. Set up of the chemostat experiments. 601 Medium: $0.8 \mu \mathrm{m}$-filtered freshwater adjusted to the higher salinity in the plastic jar; Peristaltic pumps: pumps to move water through the chemostats; 10 l Stage I, II, III: glass bottles of 3 chemostats; Air filter and Air pump for aeration of chemostats with sterile room air; Capsule filter: filter for sterilizing the end product; End product: plastic container for collecting water after the last chemostat the outflow every second day, but analyses were only performed on selected subsamples.

HS medium. For the medium, natural freshwater samples $(\sim 2 \times 60$ l) were collected into acid-washed $(0.2 \mathrm{M}$ $\mathrm{HCl}$ ) PE containers (20 l each) from 2 humic-rich streams of the same drainage system in the hinterland of the Wadden Sea (Esens region, northwestern Germany, total DOC up to $5.2 \mathrm{mM} \mathrm{C}$ ) on 11 May and 2 December 2003. The first sample was used for the Wad30 experiment and the second sample for the inocula of the Wes5 and Wes15 experiments. To remove the freshwater bacteria, the water was passed through a $0.1 \mu \mathrm{m}$ cartridge using tangential ultrafiltration (Amicon-Millipore) on the same day. The filtered bulk water was used as the main component of the growth medium for the chemostats but was amended with $20 \mu \mathrm{M}$ of $\mathrm{NH}_{4} \mathrm{Cl}$ and $5 \mu \mathrm{M}$ of $\mathrm{HNa}_{2} \mathrm{PO}_{4}$ and a vitamin solution $\left(1 \mathrm{ml} \mathrm{l}^{-1}\right)$. The vitamin solution in $100 \mathrm{ml}$ of distilled water consisted of $4 \mathrm{~g} \mathrm{4-}$ aminobenzoe acid, $1 \mathrm{mg} \mathrm{D}(+)$-biotin, $10 \mathrm{mg}$ nicotine acid, $5 \mathrm{mg} \mathrm{Ca}-\mathrm{D}(+)$ panthotenate, $15 \mathrm{mg}$ pyridoxine $\times \mathrm{HCl}$, $10 \mathrm{mg}$ thiamine $\times 2 \mathrm{HCl}$, and $5 \mathrm{mg}$ vitamin B12. The salinity of the medium was adjusted to the in situ salinity level from where the bacterial inoculum was taken, adding 1.51 (for salinity 5) or 4.51 (for salinity 15) of artificial seawater medium (ASW) of a salinity of 200 (1 l ASW salinity of 200, solution A [500 ml]: $\mathrm{NaCl}, 135.93 \mathrm{~g}$; $\mathrm{Na}_{2} \mathrm{SO}_{4}, 22.74 \mathrm{~g}_{i} \mathrm{KCl}, 3.84 \mathrm{~g}_{i} \mathrm{NaHCO}_{3}, 1.11 \mathrm{~g}_{i} \mathrm{KBr}$, $0.55 \mathrm{~g}_{;} \mathrm{H}_{3} \mathrm{BO}_{3}, 0.15 \mathrm{~g} ; \mathrm{NaF}, 0.02 \mathrm{~g}$ and solution $\mathrm{B}$ [500 ml]: $\mathrm{MgCl}_{2} \times 6 \mathrm{H}_{2} \mathrm{O}, 61.44 \mathrm{~g}_{;} \mathrm{CaCl}_{2} \times 2 \mathrm{H}_{2} \mathrm{O}, 8.61 \mathrm{~g} ; \mathrm{SrCl} \times$ $6 \mathrm{H}_{2} \mathrm{O}, 0.14 \mathrm{~g}$ ) to $60 \mathrm{l}$ of the filtered freshwater medium (Parsons et al. 1984). For adjusting salinity to 30, $6 \mathrm{l}$ of $300 \mathrm{ASW}$ were added to $60 \mathrm{l}$ of the filtered freshwater medium. DOC concentrations before and after the salinity adjustment were similar, indicating that no flocculation and thus abiotic DOC removal occurred. The medium was stored in 601 acid-washed plastic jars (total volume of $120 \mathrm{l}$ ) and sterilized silicon tubing was used to pump the medium into the chemostats.

Abiotic DOC removal. A control experiment to examine whether processes other than bacterial decomposition, e.g. abiotic flocculation, contributed to DOC removal was carried out in June 2007. Therefore, a batch experiment with HS-rich stream water, prefiltered through a $0.1 \mu \mathrm{m}$ cartridge using tangential ultrafiltration and adjusted to salinities of 1,15 , and 30 , was set up and incubated for $7 \mathrm{~d}$ at $15^{\circ} \mathrm{C}$ in the dark but without a bacterial inoculum. Periodically, subsamples were withdrawn to analyze concentrations of DOC and total organic carbon (TOC).

DOC. For DOC measurements, $15 \mathrm{ml}$ subsamples were filtered (0.2 $\mu \mathrm{m}$ Gelman Acrodisc HT Tuffryn), and analysis was performed by combustion at $850^{\circ} \mathrm{C}$ and IRdetection with a multi N/C 3000 analyzer (Analytik Jena) or with a Shimadzu TOC-VCPH (abiotic control experiment). Samples for TOC analysis were not pre-filtered. 
The samples were acidified prior to analysis with $50 \mu \mathrm{l}$ of $50 \% \mathrm{H}_{3} \mathrm{PO}_{4}$. Calibration was done using a K-hydrogenphthalate solution as a standard in the range from 0.5 to $10 \mathrm{mM}$ of carbon (CV 0.8 to $3.5 \%$ ). All glassware used was acid-washed and pre-combusted at $500^{\circ} \mathrm{C}$ for $2 \mathrm{~h}$.

Extraction of HS using XAD resins. Water samples, acidified to $\mathrm{pH} 2.0$, were pre-filtered through a $0.1 \mu \mathrm{m}$ cartridge using tangential flow ultrafiltration (AmiconMillipore). The high-molecular-weight material of the DOC was isolated by column chromatography of 10 to 301 of filtered sample using a series of XAD-8 and XAD-4 resins (DAX-4 and DAX-8, Sigma-Aldrich) (Thurman \& Malcolm 1981, Malcolm \& MacCarthy 1992). HS were eluted from the XAD-8 resin with $0.1 \mathrm{~N}$ $\mathrm{NaOH}$. The separation with the XAD-8 resin provides HA and FA, which are hydrophobic, whereas XAD-4 resin separates HPA. The eluate from the XAD-8 resin was separated into $\mathrm{FA}$ and $\mathrm{HA}$ fractions at $\mathrm{pH} 1$ (overnight at $4^{\circ} \mathrm{C}$, followed by centrifugation at $4000 \times g$ ). All samples of HA, FA and HPA were reconcentrated separately onto the resin on which they were isolated, desalted by elution with $0.1 \mathrm{~N} \mathrm{NaOH}$ on cation exchange resins, vacuum concentrated, and freeze-dried. For rough mass balance calculations, the differences in DOC were measured before the sample was applied on XAD-8, after XAD-8/before XAD-4, and after XAD-4. The yield of HA, FA, and HPA was measured by weighing the material after freeze-drying.

Total number of bacteria (TNB) and bacterial production (BP). Bacteria were fixed with formaldehyde (final concentration $1 \%$ ) and stained with SYBR Green I as described by Lunau et al. (2005). Briefly, sub-samples (usually 1 to $3 \mathrm{ml}$ ) were filtered onto $0.2 \mu \mathrm{m}$ black isopore filters (Whatman) and washed with $1 \mathrm{ml}$ of $1 \times$ TAE buffer ( $\mathrm{pH}$ 8). The filter was placed on a glass slide into the embedding solution containing SYBR Green I and covered by a cover slip. About 250 to 300 cells were counted using a Zeiss Axiolab microscope at $1000 \times$ magnification (lamp: HBO 50, filter set: Zeiss, excitation 450-490, FT 510, LP 515). BP was determined using the standard ${ }^{14} \mathrm{C}$-leucine incorporation method (Simon \& Azam 1989). Briefly, $60 \mathrm{nM}$ (final concentration) of ${ }^{14} \mathrm{C}$ leucine (specific activity $10.8 \mathrm{GBq}$ $\mathrm{mmol}^{-1}$, Hartmann Analytic), ensuring saturation of the uptake systems, was added to triplicate $5 \mathrm{ml}$ samples and duplicate formaldehyde-killed controls and incubated for $1 \mathrm{~h}$ in the dark. Incubation was stopped by adding formaldehyde (final concentration $1 \%$ ), and protein was extracted using $5 \%$ ice-cold trichloroacetic acid (TCA) for $5 \mathrm{~min}$. Thereafter, samples were filtered onto $0.45 \mu \mathrm{m}$ nitrocellulose filters and rinsed 6 times with ice-cold 5\% TCA. Dried filters were dissolved with ethylacetate and radioassayed by liquid scintillation counting. Biomass production was calculated according to Simon \& Azam (1989).

\section{RESULTS}

The initial DOC concentration in the medium of the Wad30 experiment was $3.8 \mathrm{mM} \mathrm{C}, 0.9 \mathrm{mM}$ lower than that in the Wes5 and Wes15 experiments, and the accumulated fractions of HS in the Wad30 experiment amounted to $84 \%$ of DOC compared to $74 \%$ in the latter (see Tables 1 \& 2, Fig. 2). The chemostat experiments resulted in distinct decomposition steps of the DOC in the various stages of the continuous cultures (Table 1). There were 2 controlling parameters: the dilution rate of the chemostat $\left(0.1 \mathrm{~d}^{-1}\right.$ for Wad30 and $0.15 \mathrm{~d}^{-1}$ for Wes5 and Wes15), and the substrate concentration in the medium. Both controlling parameters were kept constant during the course of 1 experiment in order to reach steady state conditions between the decomposition of substrates and the renewal of the substrate pool by fresh HS.

\section{Decomposition of DOC}

In the Wad30 experiment, the decomposition of DOC was substantial. The major decomposition took place from filling up the chemostat on Day 8 to Day 17 in Stage I. Later, DOC was further decomposed only very little

Table 1. Concentrations and decomposition of DOC $(\triangle \mathrm{DOC} \%)$ and growth efficiency (GE) in the 3 stages of the 3 continuous culture experiments (Wad30: Wadden Sea inoculum at salinity 30; Wes15, Wes5: Weser estuary inocula at salinities 15 and 5 , respectively). $\triangle \mathrm{DOC} \%$ was determined as the difference of DOC concentrations at the inflow and outflow of the chemostat stages relative to that of the previous stage and as that of Stage III relative to the medium (total). GE was calculated as the ratio of bacterial production over $\triangle \mathrm{DOC}$ in the chemostat stages (see Figs. 2 \& 3). nd: not determined

\begin{tabular}{|lccc|}
\hline Experiment & DOC (mM C) & $\Delta$ DOC $(\%)$ & GE $(\%)$ \\
\hline Wad30 & & & \\
Medium & 3.80 & & \\
Stage I & 2.05 & 46.4 & 11.9 \\
Stage II & 1.88 & 9.7 & 43.1 \\
Stage III & 1.33 & 26.4 & 22.4 \\
Total & & 64.4 & \\
Wes15 & & & \\
Medium & 4.73 & & \\
Stage I & 4.85 & 0.0 & nd \\
Stage II & 4.72 & 2.6 & 67.0 \\
Stage III & 4.5 & 4.7 & 38.9 \\
Total & & 4.8 & \\
Wes5 & & & \\
Medium & 4.73 & & \\
Stage I & 4.71 & 0.5 & 5.78 \\
Stage II & 4.71 & 0.0 & nd \\
Stage III & 4.7 & 0.2 & 12.98 \\
Total & & 0.7 & \\
\hline
\end{tabular}


(Figs. 2 \& 3). DOC decomposition in Stage III was higher than in Stage II, as shown by the substantially lower DOC concentrations. DOC mean values between Days 17 and 51 in chemostat Stages I and II and in Stage III between Days 32 and 51 were significantly lower than that in the medium ( $t$-test, $\mathrm{p}<0.01$, Fig. 2). DOC decomposition in the duplicates was not significantly different $(t-$ test, $\mathrm{p}=0.91)$. The highest decomposition occurred in Stage I ( $\triangle$ DOC: $1.76 \mathrm{mM} C$ ), whereas in Stages II and III, an additional 0.2 and $0.5 \mathrm{mM} \mathrm{C}$ were decomposed. The cumulative decomposition over the 3 stages added up to $64.4 \%$ of the DOC in the growth medium, from $3.8 \pm 0.3$ to $1.38 \pm 0.49 \mathrm{mM} \mathrm{C}$ in the outflow. In the chemostats with lower salinities and a higher dilution rate $\left(0.15 \mathrm{~d}^{-1}\right.$; Wes15 and Wes5) no significant DOC decomposition occurred (Figs. $2 \& 3$ ). A decrease in DOC was noticeable in the Wes15 experiment, from $4.73 \pm 0.02$ to 4.50 $\pm 0.24 \mathrm{mM} \mathrm{C}$ as a cumulative decrease, but was nonsignificant (ANOVA, $p=0.108$ ). The decrease in DOC was also non-significant in the Wes5 experiment, as DOC concentrations in the medium and the 3 chemostat stages remained similar, between $4.73 \pm 0.02$ and $4.70 \pm$ 0.18 mM C (ANOVA, $p=0.99$ ).

The batch experiment without a bacterial inoculum, the abiotic control, did not yield any significant change in concentration of TOC or DOC in any of the salinity treatments over the incubation period of $7 \mathrm{~d}$, despite DOC concentrations twice as high as for the chemostat experiments (Fig. 4). Concentrations of TOC and DOC

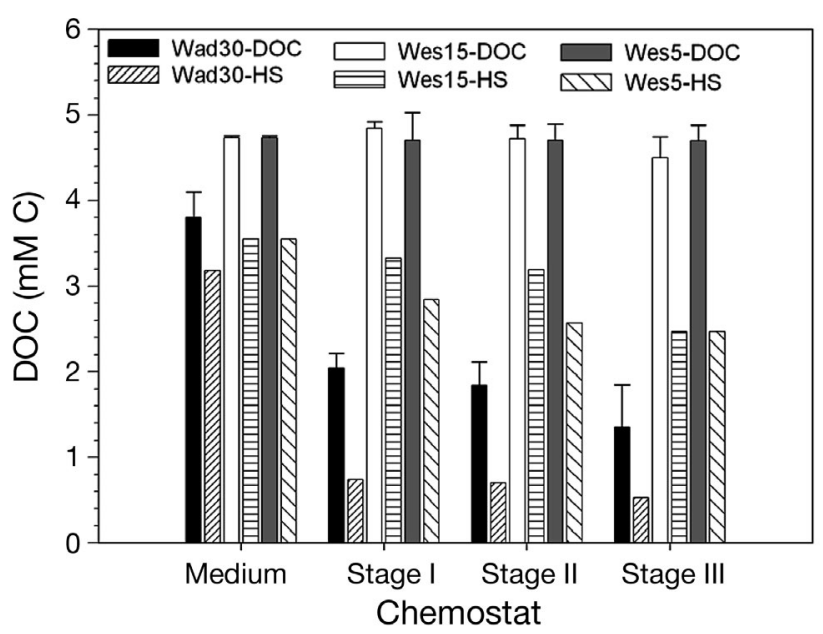

Fig. 2. Mean concentration of dissolved organic carbon (DOC) and of organic carbon bound in humic substances (HS) of the media, and chemostat Stages I, II, and III of the Wad30 (Wadden Sea inoculum at salinity 30), Wes15 and Wes5 (Weser extuary inocula at salinities 15 and 5, respectively) experiments. Given are mean values \pm SD (only for DOC) of DOC subsamples collected over the incubation period after all 3 stages. See Fig. 3 for the incubation periods of the stages of the 3 experiments. The Wad30 experiment was run in duplicate, and the Wes15 and Wes5 experiments were run in 1 replicate
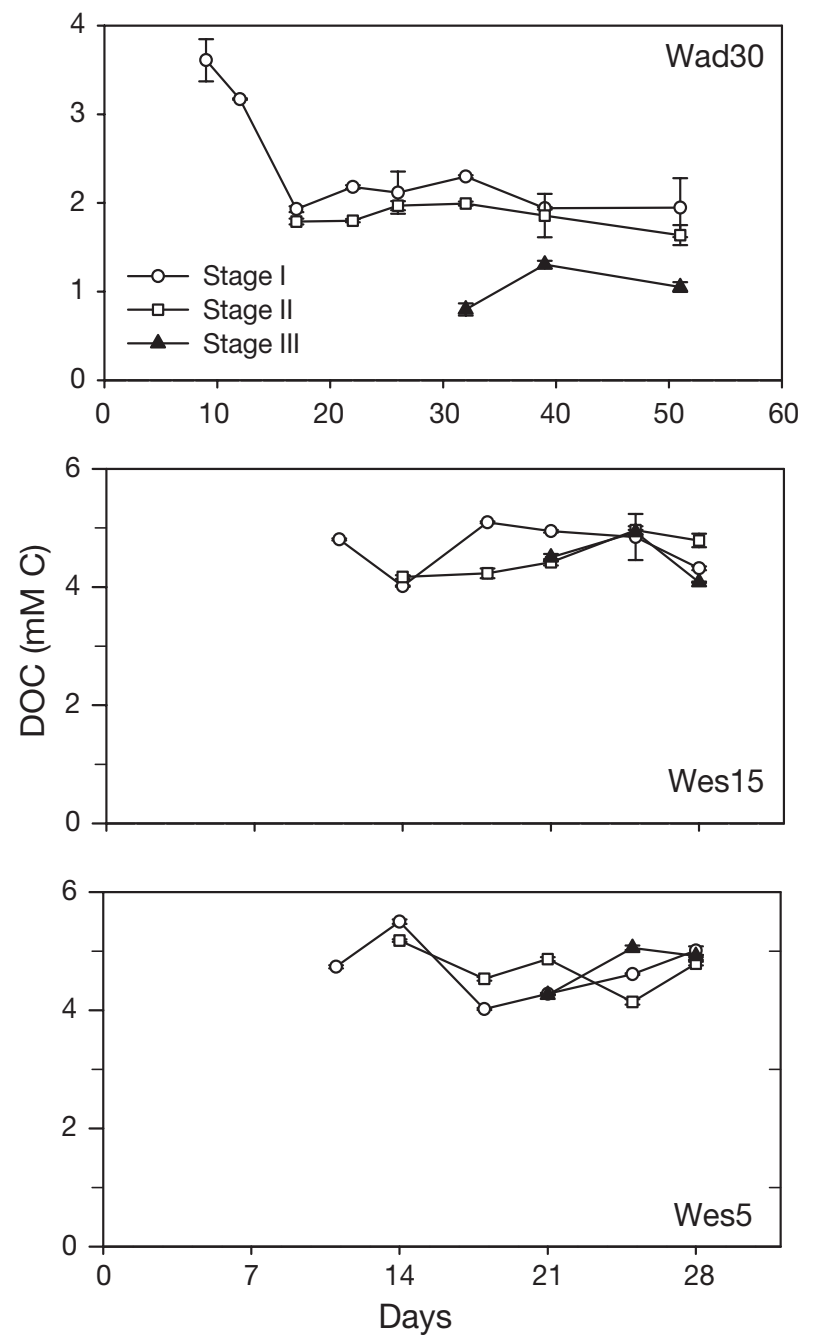

Fig. 3. Time course of DOC concentrations in the various chemostat stages of the Wes5, Wes15, and Wad30 experiments. Stage II started to run $5 \mathrm{~d}$ (Wes5, Wes15) and $8 \mathrm{~d}$ (Wad30), and Stage III 18 (Wes5, Wes15) and $24 \mathrm{~d}$ (Wad30) after the start of Stage I. The initial samples of Stage I in the 3 experiments analyzed were from Day 9 (Wad30) and Day 11 (Wes15, Wes5). Earlier samples than shown from Stages II and III were not available. Note the different scales

were similar in the salinity 1 and 30 treatments, whereas TOC concentrations were slightly higher than DOC concentrations in the salinity 15 treatment.

\section{HS fractions}

HS constituted $49 \%$ of DOC in Wad30, $61 \%$ in Wes5, and $67 \%$ in Wes15 experiments, respectively. These percentages were calculated by comparing the DOC concentration in the initial sample (before extraction on XAD resins) and the sample after extraction on both XAD columns. 


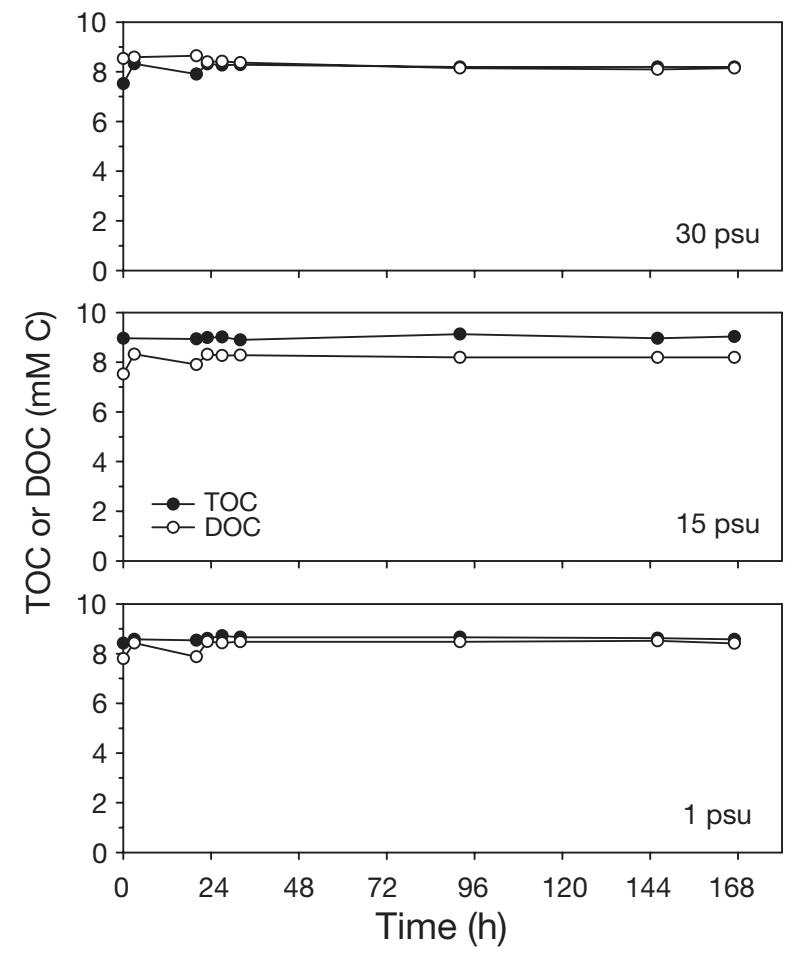

Fig. 4. Concentrations of TOC and DOC during a batch experiment in which $0.1 \mu \mathrm{m}$ pre-filtered humic-rich water adjusted to salinities 1, 15, and 30 was incubated abiotically for $7 \mathrm{~d}$ at $15^{\circ} \mathrm{C}$

The HA fraction was the lowest in all experiments and chemostat stages and generally showed a decreasing trend from the medium to the outlet of chemostat Stage III with the highest decrease in Stage I (Fig. 5). This fraction constituted 13 to $26 \%$ of DOC in the medium, but only 3.0 to $12.4 \%$ in chemostat Stage III. The FA and HPA fractions were substantially larger than that of HA in all experiments. The FA fraction decreased substantially in chemostat Stage I of the Wad30 experiment, but increased in the following stages and also in the chemostats of the Wes5 experiment relative to the medium. In the Wes15 experiment, the FA fractions exhibited large variations among the various stages (Fig. 5). The HPA fraction systematically decreased in the chemostats of the Wad30 and Wes5 experiments, mainly in Stage I, and exhibited inverse patterns to the dynamics of the FA fractions. In the Wes15 experiment, large but inconsistent fluctuations of this fraction occurred.

The accumulated HS fractions in the 3 experiments accounted for 74 to $84 \%$ of total DOC in the medium (Table 2). During the sequential decomposition, their concentrations continuously decreased (Fig. 2), to $15 \%$ of the initial HS concentration in the Wad30 experiment and to $69 \%$ in the other 2 experiments. The HS fractions as percentages of total DOC also decreased
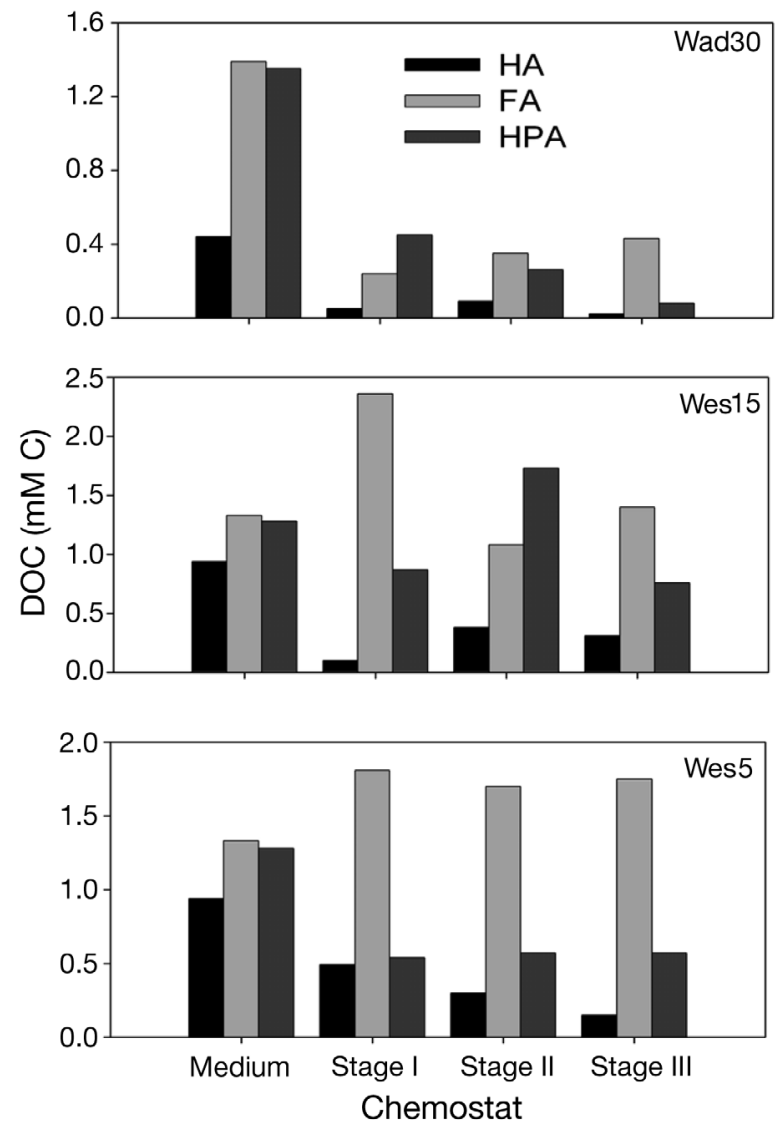

Fig. 5. Concentrations of humic acids (HA), fulvic acids (FA), and hydrophilic acids (HPA) in media of chemostat Stages I,

II, and III of the Wad30, Wes15, and Wes5 experiments

during the experiments, to $41 \%$ in the Wad30 experiment and to $54 \%$ in the other 2 experiments (Table 2).

\section{Abundance and growth parameters of bacteria}

TNB was highest in chemostat Stage I of the Wad30 experiment and decreased to significantly lower numbers in the later stages (Fig. 6). Numbers were not significantly different between the duplicates of the Wad30 experiment $(t$-test, $\mathrm{p}=0.18)$. In the Wes15 and

Table 2. Proportions of humic substances (HS) as the sum of the fractions fulvic acids (FA), humic acids (HA), and hydrophilic acids (HPA) as a percentage of total DOC in the 3 experiments, media and chemostat stages as shown in Fig. 2

\begin{tabular}{|lccc|} 
& Wad30 & Wes15 & Wes5 \\
\hline Medium & 84 & 74 & 75 \\
Stage I & 36 & 69 & 69 \\
Stage II & 38 & 69 & 63 \\
Stage III & 41 & 55 & 53 \\
\hline
\end{tabular}


Wes5 experiments, TNB fluctuated without a clear trend among the various stages.

Dynamics of BP in the chemostat stages of the Wad30 experiment (duplicates did not differ, $t$-test, $\mathrm{p}=$ 0.52) were similar to TNB, also with highest rates in Stage I (Fig. 6). Differences to the later stages were significant (ANOVA, p < 0.01). In the Wes15 experiment, similar patterns were observed but with lower values in Stage I (ANOVA, p = 0.035). In the Wes5 experiment, BP rates remained similar among the 3 stages.

Bacterial growth efficiency (GE), calculated as the ratio of $\mathrm{BP}$ over $\triangle \mathrm{DOC}$ in the stages of the chemostats, varied from 6 to $67 \%$ without clear differences among the 3 experiments and chemostat stages (Table 1). Hence bacterial DOC decomposition resulted in conversion to bacterial biomass and remineralization to inorganic carbon to varying extents. Relatively low GE occurred in Stage I of the Wad30 and Wes5 experi-

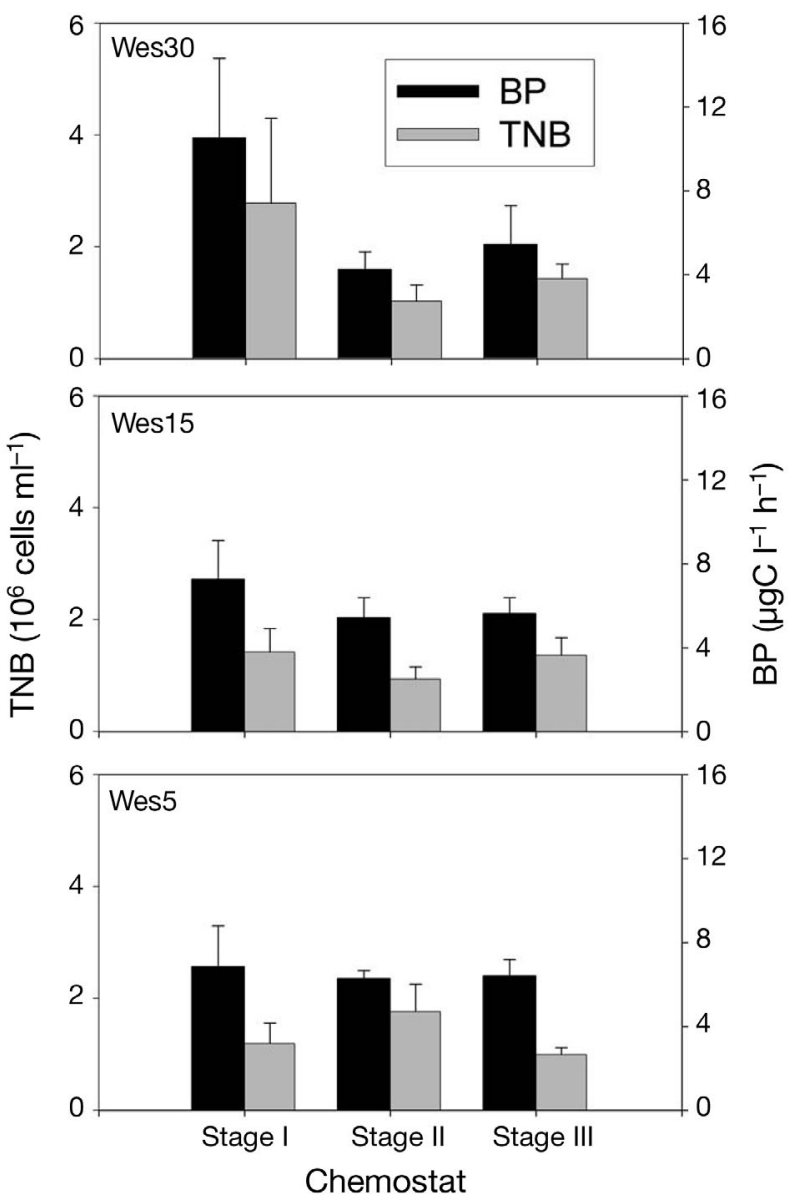

Fig. 6. Total numbers of bacteria (TNB) and bacterial production (BP) in chemostat Stages I, II, and III of the Wad30 ( $\mathrm{n}=8$, $6,3)$, Wes15 $(\mathrm{n}=7,6,4)$, and Wes5 $(\mathrm{n}=7,6,4)$ experiments. Given are mean values \pm SD of subsamples collected over the incubation period since all 3 stages started to run, i.e. from Days 25 to 51 in Wad30, and from Days 18 to 51 in Wes5 and Wes15 ments and relatively high GE in Stage II of the Wad30 and Wes15 experiments.

Concentrations of labile DOC (dissolved amino acids, dissolved free neutral monosaccharides) never exceeded $0.03 \%$ of DOC (data not shown).

\section{DISCUSSION}

The humic-rich DOC was decomposed to more than $60 \%$ in the Wad30 experiment, and mainly in chemostat Stage I from filling up the chemostat on Day 8 until Day 17, whereas in the other 2 experiments at salinities of 15 and 5 (Wes15, Wes5), no detectable decomposition occurred. These differences were also reflected by the higher bacterial numbers and production rates in the Wad30 chemostat. At the high salinity condition, all 3 HS fractions were reduced substantially, whereas at a salinity of 5, only the HA and HPA fractions decreased, and at 15 only the HA fraction decreased. At a salinity of 5, the FA fraction increased. However, HS in total were also reduced at the lower salinities, although by $<30 \%$. These findings indicate that at a salinity typical of the polyhaline estuarine zone and close to that occurring in the coastal sea, HS are substantially decomposed, whereas at lower salinities, very little, if any, bacterial decomposition of humic-rich DOC occurs, even though the bacteria do transform the various humic fractions.

Our analyses and the abiotic control experiment gave evidence that the decrease in DOC concentrations in the course of the chemostat experiments was predominantly mediated by the decomposition activities of the bacteria added as inoculum. Abiotic processes such as flocculation did not occur after adjusting the freshwater medium to salinities of 1,15 , and 30 . In addition, no DOC losses occurred during a batch experiment with humic-rich freshwater DOC adjusted to higher salinities and without a bacterial inoculum (Fig. 4).

The major differences among the 3 experiments were the bacterial inocula, suggesting that the bacterial community originating from the Wadden Sea (Wad30) was most competent in degrading the humicrich DOC. It has been shown that the bacterial communities from the various locations of different salinities are phylogenetically different (Selje \& Simon 2003, Stevens et al. 2005). However, functional differences and in particular the major players in the decomposition of humic-rich DOC in these communities are still unknown. In addition to the inocula, the high ionic strength may have facilitated the decomposition by the polyhaline bacterial community. Wikner et al. (1999) showed that increasing ionic strength enhances the bacterial decomposition of allochthonous DOC even at 
a salinity $<5$, although another study did not find enhanced bacterial decomposition of humic-rich DOC at increased ionic strength (Søndergaard et al. 2003). From our results, we can conclude that the polyhaline bacterial community was most effective in decomposing the humic-rich DOC, but we do not know whether and how much the high ionic strength under the polyhaline conditions facilitated the enhanced bacterial decomposition. These findings of enhanced bacterial decomposition of humic-rich DOC by a polyhaline bacterial community at high salinities relative to that by oligohaline bacterial communities of the upper sections of the Weser estuary are consistent with reports of a generally conservative mixing of DOC in these estuarine regions. Such enhanced bacterial decomposition provides an explanation for the rapid disappearance of DOC in the outer estuarine regions at high salinities (Cauwet 2002, McKenna 2004, Servais \& Garnier 2006).

Other differences were the $0.1 \mathrm{~d}^{-1}$ dilution rate and incubation at $20^{\circ} \mathrm{C}$ of the Wad30 experiment compared to a dilution rate of $0.15 \mathrm{~d}^{-1}$ and incubation at $15^{\circ} \mathrm{C}$ of the Wes15 and Wes5 experiments. The higher dilution rate was intended to shift the DOC decomposition from Stage I toward Stages II and III, and the lower temperature was intended to account for the lower ambient temperature in December compared to May. The higher dilution rates and lower temperature in the Wes 15 and Wes5 experiments could have slowed down or even prevented the establishment of a well-adapted bacterial community in the various stages, thus preventing any decomposition of the DOC. However, we assume that this was not the case and that the different decomposition and transformation patterns were a result of the different metabolic properties of the bacterial communities. The higher dilution rate in these experiments would have shifted the decomposition from Stage I to Stages II or III, but a significant DOC decomposition should have been detected, despite the higher dilution rate.

The lower incubation temperature of the Wes5 and Wes15 experiments may have reduced bacterial DOC decomposition. Assuming that bacterial growth at $15^{\circ} \mathrm{C}$ compared to $20^{\circ} \mathrm{C}$ is lower by $30 \%$ (Shiah \& Ducklow 1994), the difference of $5^{\circ} \mathrm{C}$ would also have reduced the DOC decomposition in the Wes5 and Wes15 experiments by $30 \%$ compared to the Wad30 experiment. However, the difference we found was far greater, suggesting that other factors led to the low DOC decomposition in the former 2 experiments.

Other factors that could have affected the different DOC decomposition rates between the Wad30 and Wes 5 and Wes 15 experiments were nitrogen limitation and qualitative differences of the HS collected in May (Wad30) and December (Wes5 and Wes15). We added
$20 \mu \mathrm{M}$ nitrogen to the DOC medium, which had an ambient concentration of 30 to $50 \mu \mathrm{M}$ N (S. Koelsch \& H. Brumsack unpubl. data). Therefore, N-limitation appeared rather improbable and would have affected all 3 experiments similarly. Concentrations of $\mathrm{HS}$ in December were higher than in May, but their relative proportions as \% of DOC were lower (Fig. 2). Concentrations of FA and HPA were similar in both months, and only the concentration of HA was lower in May compared to December. The latter fraction was the only one that was decomposed consistently in all 3 experiments, whereas the other fractions were only consistently decomposed in the Wad30 experiment. We assume that the composition of the FA and HPA fractions was similar in May and December and that the low DOC decomposition of the Wes5 and Wes15 experiments was not due to a more refractory nature of these compounds in December compared to May. However, we cannot completely rule out this possibility because we did not examine the molecular structure of these HS fractions by more refined methods than XAD extraction.

Our results also indicate that the bacterial GE can vary largely among different bacterial communities and different decomposition stages. However, we could not identify consistent patterns of GE in relation to the growth stages and/or salinity ranges.

Thus far, decomposition of humic-rich DOC by bacterial communities at varying salinities has been studied very little despite the fact that the DOC reduction in the estuarine transition zone and coastal sea is not well understood. Our study was the first to apply chemostats, whereas previous studies have used batch cultures (Wikner \& Hagström 1999, Søndergaard et al. 2003). Applying batch cultures does not allow us to distinguish different degradation stages. Labile substrates are used first and select for a specific bacterial community and may introduce unfavorable conditions for a succeeding community, potentially degrading the more refractory material. Further, batch cultures are limited by the small substrate volume and the fact that no steady state is established. Sequential chemostats such as those we applied do not suffer from the abovementioned shortcomings and appear to be much more suitable for these investigations. For degradation experiments, these chemostats better meet the multi-G (G: discrete substrate pool) model of a continuum of discrete DOC substrate pools (Westrich \& Berner 1984, Raymond \& Bauer 2000). The 3 stages we set up enabled us to distinguish among the various levels of DOC degradation and enabled the bacterial communities to adapt to the various growth conditions. The continuous supply of fresh material ensured an unchanged substrate pool during the entire experiment. In fact, this approach showed that the highest decomposition 
occurred in the Wad30 experiment in the early phase of Stage I, from filling of the chemostat until Day 17, after the end of the initial phase, and in Stage III. Hence, our finding of a surprisingly high decomposition of humic-rich DOC of a polyhaline bacterial community in sequential chemostats may provide a more realistic scenario of the role of heterotrophic bacteria in the estuarine turnover and loss of DOC than results obtained from batch culture experiments.

HS constituted 36 to $84 \%$ of total DOC, and proportions decreased from the medium to the last chemostat stage. These proportions are in the same range as reported in other studies (e.g. McKnight \& Aiken 1998, McKenna 2004). We observed some variability among the 3 HS fractions during the experiments; the FA fraction increased in the Wad30 experiment from Stage I to Stage III and in the Wes5 experiment from the medium to Stage I. These naturally occurring macromolecular substances are most complex and heterogeneous and cannot be well characterized chemically. They are defined operationally according to their solubility at low $\mathrm{pH}$ or adsorbed to hydrophobic macroporous resins such as XAD (Thurman \& Malcolm 1981).

The non-HS fraction, which is not adsorbed at all to or eluted by methanol from XAD resins, includes hydrophilic low molecular weight (LMW, <1.2 kDa) and hydrophobic components (McKnight \& Aiken 1998). We did not intend to fully characterize the nonHS fraction, but the dissolved amino acids and dissolved free carbohydrates constituted only minor proportions (data not shown). Due to the large volume needed for the fractionation and extraction procedure, we could analyze only 1 replicate. Even though we must consider some analytical variability of the results, the budget of all 3 fractions shows that the total amount of HS decreased in all 3 experiments, indicating that the shifts among the fractions were accommodated. We assume that our findings show that bacterial decomposition modifies the adsorptive properties of the HS and renders substantial amounts of HS nonhumic.

Our findings also provide some evidence that bacterial decomposition at first transforms HA and HPA to FA, a LMW fraction. This notion implies that the distinction between HS and non-HS does not refer specifically to their bacterial degradability but strictly to their adsorptive properties. Further, this notion is consistent with the size-reactivity continuum model proposed by Amon \& Benner (1996), hypothesizing that the reactivity of DOC is inversely related to the molecular weight. In Amon \& Benner $(1994,1996)$ the authors showed that bacteria decompose preferentially high molecular weigh (HMW) DOC (>1 kDa) and that LMW DOC is much more recalcitrant. Hence, we assume that the loss of HS in our experiments was mainly due to the preferred bacterial decomposition of the HMW DOC, which consisted of high proportions of HS, and left behind recalcitrant LMW DOC with a significantly lower proportion of HS.

Our findings complement previous notions of the transformation and losses of riverine and humic-rich DOC during its estuarine passage to the coastal sea. They provide the framework for the following scenario of DOC removal during this passage. In the lower salinity range, flocculation and photochemical reactions (Sholkovitz 1976, Sholkovitz et al. 1978, Moran \& Zepp 1997, Obernosterer \& Herndl 2000, Obernosterer et al. 2001, Kerner et al. 2003) appear to be the most important processes of DOC transformation, leading, however, only to minor DOC degradation. This implies that the DOC is largely recalcitrant and explains its conservative behavior of mixing with seawater, i.e. dilution without significant bacterial decomposition (Cauwet 2002, Servais \& Garnier 2006). If non-conservative mixing occurs, it is mainly the result of production of labile DOC in the estuarine region and a function of the residence time of the DOC (McKenna 2004). Removal of the recalcitrant and humic-rich DOC occurs predominantly in the polyhaline estuarine region and possibly in the adjacent coastal sea and is mediated by its bacterial decomposition and breakdown to more recalcitrant LMW compounds. The effectiveness of the bacterial decomposition is a function of environmental conditions such as temperature, but also of the residence time. Hence, bacterial DOC degradation in extended and tidally affected shallow coastal ecosystems such as the Wadden Sea would be higher than in regions of riverine discharge directly into deeper coastal regions and in river plumes in delta regions and in permanently cold regions like the Arctic Ocean (Opsahl et al. 1999).

Acknowledgements. This work was supported by a Marie Curie Fellowship of the European Commission's Environment and Sustainable Development Program (EVK3-CT-200250020 to V.K.) and by a grant from the Deutsche Forschungsgemeinschaft (Si 360/22-1). We appreciate valuable suggestions of 3 anonymous reviewers on an earlier version of this manuscript.

\section{LITERATURE CITED}

Aiken GR, McKnight DM, Wershaw RL, MacCarthy P (1985) Humic substances in soil, sediment, and water-geochemistry, isolation, and characterization. Wiley, New York

Amon RMW, Benner R (1994) Rapid-cycling of high-molecular-weight dissolved organic matter in the ocean. Nature 369:549-552

> Amon RMW, Benner R (1996) Photochemical and microbial consumption of dissolved organic carbon and dissolved oxygen in the Amazon River system. Geochim Cosmochim Acta 60:1783-1792 
Cauwet G (2002) DOM in the coastal zone. In: Hansell DA, Carlson CA (eds) Biogeochemistry of marine dissolved organic matter. Academic Press, San Diego, CA, p 579-609

Hedges JI, Keil RG, Benner R (1997) What happens to terrestrial organic matter in the ocean? Org Geochem 27: 195-212

Ishiwatari R (1992) Macromolecular material (humic substance) in the water column and sediments. Mar Chem 39:151-166

Kerner M, Hohenberg H, Ertl S, Reckermann M, Spitzy A (2003) Self-organization of dissolved organic matter to micelle-like microparticles in river water. Nature 422: 150-154

Lunau M, Lemke A, Walther K, Martens-Habbena W, Simon $M$ (2005) An improved method for counting bacteria from sediments and turbid environments by epifluorescence microscopy. Environ Microbiol 7:961-968

Malcolm RL, MacCarthy P (1992) Quantitative evaluation of $\mathrm{XAD}-8$ and XAD-4 resins used in tandem for removing organic solutes from water. Environ Int 18:597-607

Mannino A, Harvey HR (2004) Black carbon in estuarine and coastal ocean dissolved organic matter. Limnol Oceanogr 49:735-740

McKenna JH (2004) DOC dynamics in a small temperate estuary: simultaneous addition and removal processes and implications on observed nonconservative behavior. Estuaries 27:604-616

McKnight D, Aiken G (1998) Sources and age of aquatic humus. In: Hessen D, Tranvik L (eds) Aquatic humic substances. Ecology and biochemistry. Springer, New York, p 9-39

Moran MA, Zepp RG (1997) Role of photoreactions in the formation of biologically labile compounds from dissolved organic matter. Limnol Oceanogr 42:1307-1316

Obernosterer I, Herndl GJ (2000) Differences in the optical and biological reactivity of the humic and nonhumic dissolved organic carbon component in two contrasting coastal marine environments. Limnol Oceanogr 45: $1120-1129$

Obernosterer I, Reitner B, Herndl GJ (1999) Contrasting effects of solar radiation on dissolved organic matter and its bioavailability to marine bacterioplankton. Limnol Oceanogr 44:1645-1654

Obernosterer I, Sempere R, Herndl GJ (2001) Ultraviolet radiation induces reversal of the bioavailability of DOM to marine bacterioplankton. Aquat Microb Ecol 24:61-68

- Ogawa H, Amagai Y, Koike I, Kaiser K, Benner R (2001) Production of refractory dissolved organic matter by bacteria. Science 292:917-920

Opsahl S, Benner R (1997) Distribution and cycling of terrigenous dissolved organic matter in the ocean. Nature 386:480-482

Editorial responsibility: Craig Carlson, Santa Barbara, California, USA
Opsahl S, Benner R, Amon RMW (1999) Major flux of terrigenous dissolved organic matter through the Arctic Ocean. Limnol Oceanogr 44:2017-2023

Parsons T, Maita Y, Lalli C (1984) A manual of chemical and biological methods for seawater analysis. Pergamon, New York

Raymond PA, Bauer JE (2000) Bacterial consumption of DOC during transport through a temperate estuary. Aquat Microb Ecol 22:1-12

Selje N, Simon M (2003) Composition and dynamics of particle-associated and free-living bacterial communities in the Weser estuary, Germany. Aquat Microb Ecol 30:221-237

Servais P, Garnier J (2006) Organic carbon and bacterial heterotrophic activity in the maximum turbidity zone of the Seine estuary (France). Aquat Sci 68:78-85

Shiah FK, Ducklow HW (1994) Temperature and substrate regulation of bacterial abundance, production and specific growth rate in Chesapeake Bay, USA. Mar Ecol Prog Ser 103:297-308

Sholkovitz ER (1976) Flocculation of dissolved organic and inorganic matter during the mixing of river water and seawater. Geochim Cosmochim Acta 40:831-845

Sholkovitz ER, Boyle EA, Price NB (1978) The removal of dissolved humic acids and iron during estuarine mixing. Earth Planet Sci Lett 41:77-86

Simon M, Azam F (1989) Protein content and protein synthesis rates of planktonic marine bacteria. Mar Ecol Prog Ser 51:201-213

Søndergaard M, Stedmon CA, Borch NH (2003) Fate of terrigenous dissolved organic matter (DOM) in estuaries: aggregation and bioavailability. Ophelia 57: 161-176

Stevens H, Stübner M, Simon M, Brinkhoff T (2005) Phylogeny of Proteobacteria and Bacteroidetes from oxic habitats of a tidal flat ecosystem. FEMS Microbiol Ecol 54:351-365

Thurman EM, Malcolm RL (1981) Preparative isolation of aquatic humic substances. Environ Sci Technol 15: 463-466

Tranvik L (1998) Degradation of dissolved organic matter in humic waters by bacteria. In: Hessen D, Tranvik L (eds) Aquatic humic substances: ecology and biogeochemistry. Springer, New York, p 259-284

Westrich JT, Berner RA (1984) The role of sedimentary organic matter in bacterial sulfate reduction-the G model tested. Limnol Oceanogr 29:236-249

> Wikner J, Hagström ^̊ (1999) Bacterioplankton intra-annual variability: importance of hydrography and competition. Aquat Microb Ecol 20:245-260

Wikner J, Cuadros R, Jansson M (1999) Differences in consumption of allochthonous DOC between a lake and an estuary in a temperate watershed. Aquat Microb Ecol 17:289-299

Submitted: July 12, 2007; Accepted: August 6, 2008 Proofs received from author(s): September 12, 2008 